\title{
Immunolocalization of Estrogen Receptor Alpha in Adult Female Rat Hippocampus
}

\author{
Inmunolocalización del Receptor de Estrógeno Alfa en el Hipocampo de Rata Hembra Adulta
}

*Anju Lata Rai \& **Usha Jeswar

RAI, A. L. \& JESWAR, U. Immunolocalization of estrogen receptor alpha in adult female rat hippocampus. Int. J. Morphol., 28(2):483487, 2010.

SUMMARY: The present study was planned to demonstrate the detailed immunoreactive (IR) distribution pattern of estrogen receptors (ER) in hippocampus of 15 female rats, adult, female Wistar rats in estrous phase. $30 \mu \mathrm{m}$ thick setions of hippocampal region fixed (4\% buffered paraformaldehyde) were obtained with cryostat. The sections were processed free- floating for immunolocalization of ER using, mouse monoclonal anti-ER- $\alpha$ antibody with PAP technique. The results showed presence of ER immunoreactive neurons in all the subfields of hippocampus with some variations. In cornua ammonis (CA) maximum ER positive (+ve) neurons were localized in CA3 region. Layer analysis showed maximum localization in the stratum oriens (SO) region. In other subfields and layers of CA the IR neurons were comparatively less in number. The morphological characters of all ER +ve neurons showed them to be interneurons both in CA as well as in Dentate gyrus (DG).

KEY WORDS: Estrogen receptor- $\alpha$; Estrogen receptor- $\beta$; Brain; Hippocampus; Interneurons; Cornua ammonis.

\section{INTRODUCTION}

The ovarian steroid hormone estrogen besides exerting reproductive effect has actions on the brain as well. The effects were seen earlier in hypothalamus; the classical target area for estrogen, but recent studies revealed that other brain areas i.e. the extra reproductive brain areas viz., basal forebrain, corpus striatum, hippocampus and cerebellum may also be potential sites for neurotropic influences of estrogen. It is now apparent that estrogen is much more than just a sex hormone.

The actions of estrogens were thought to be mediated by single nuclear ER until the recent cloning of ER- $b$ (Kuiper et al., 1996). ERs were thought to be present exclusively in cell nuclei initially but later their presence was demonstrated in the cytoplasm as well (Blaustein \& Olster, 1989). Distribution of classic (ER- $\alpha)$ and novel (ER- $\beta$ ) receptor differs quite markedly with moderate to high expression of ER- $\alpha$ in pituitary, kidney, epididymis and adrenal while moderate to high expression of ER- $\beta$ in prostate and lungs. Apart from classical ER- $\alpha$ and ER- $\beta$, a variety of non-ER- $\alpha$
/non-ER- $\beta$ nuclear, cytoplasmic and plasma membrane estrogen receptors exist in the brain. These include a $G$ protein-coupled receptor; a novel estrogen receptor "ER-X"; ER-46 and a putative estrogen receptor (pER) that is immunochemically, structurally, and functionally completely distinct from ER- $\alpha$ and ER $\beta$ (Toran-allerand, 2005).

Although both known ERs ( $\boldsymbol{\alpha}$ and $\beta$ ) are present in the brains of adult mammals and are co-expressed in some brain regions, there are important region specific differences in their distribution. In brain ER- $\alpha$ is localized in ventromedial hypothalamic nucleus, sub fornical organ, ventrolateral thalamic nuclei and lateral amygdaloid nuclei whereas ER- $\beta$ is localized in anterior olfactory nuclei, cerebral and piriform cortices and hippocampus (Shughrue et al., 1997).

ER expression appears to fluctuate in different physiological conditions as well as in stress (Koch \& Ehret, 1989). It was observed to be highest during pregnancy and

\footnotetext{
* Reader, I.T.S. Dental College, Greater Noida, Uttar Pradesh, INDIA.

** Assistant Professor, A.J. Institute of Medical Sciences, Kuntikana, Mangalore, Karnataka, INDIA.
} 
lactation and also fluctuate throughout the phases of rat female estrous cycle, being highest in estrous and met estrous phase (Shughrue et al., 1992).

Estrogen has been shown to influence several processes associated with hippocampal function including altering certain types of learning behaviour (O'Neil et al., 1996) decreasing the threshold to seizure activity and altering course of Alzheimer's disease (Fillit et al., 1986). Estrogen mediates some of its effects on hippocampal formation through alpha subtype of ER (ER- $\alpha)$ or through ER- $\beta$ (McEwens \& Alves, 1999). Earlier it was observed that ERs are present equally in both sexes and their occurrence has no difference with regard to their distribution and intensity of immunoreactivity within the hippocampus (Weiland $e t$ al., 1997). Later some researchers observed that ER- $\alpha$ is relatively low in the hippocampal formation compared with the ER- $\beta$ which seems to be the major ER expressed in the hippocampus (Kuiper et al., 1997; Shughrue et al., 1997; Laflamme et al., 1998; Mitra et al., 2003).

It has been observed that the density of dendritic spines in the intact rat hippocampus undergoes marked variations during estrous cycle. A higher density of dendritic spines coincides with high levels of estrogen (Woolley et al., 1990). Ovariectomy resulted in decrease in CA1 cell dendritic spines and it was prevented with estradiol treatment (Gould et al., 1990; Woolley \& McEwen 1994). Initially it was observed changes in spine density occurred through NMDA receptors, but ER have been localised in CA1 pyramidal neurons also. ER- $\alpha$ is present in CA1pyramidal neurons spines and synapses (Milner et al., 2001; Adams et al., 2002), as is ER- $\beta$ (Milner et al., 2005).

Hence we can say that neurons of the hippocampus appear to be particularly sensitive to circulating estrogen as any alteration in the levels of this hormone dramatically changes hippocampal physiology. Since this hormone act through ER it is mandatory to study its distribution in details.

As none of the articles cited above showed detailed distribution pattern of estrogen receptors within this important region of brain. The present study was undertaken to map out estrogen receptor immunoreactivity in adult female rat hippocampus during estrous phase.

\section{MATERIAL AND METHOD}

Fifteen adult female Wistar rats (body wt. 200-210g) in estrous phase of the estrous cycle (vaginal smears tested positive with presence of cornified epithelial cells), housed in the Central Animal Facility of the All India Institute of Medical Sciences with $12 \mathrm{hrslight/dark}$ photoperiod and ad libetum access to food and water, were anesthetized with Sodium Pentobarbital (50mg/kg.wt.i.p) and perfused transcardially with $4 \%$ Paraformaldehyde in $0.1 \mathrm{M}$ Phosphate buffer ( $\mathrm{pH}$ 7.4). Brains were removed and the tissue specimens (middle blocks) were sectioned on a cryostat, $30 \mu \mathrm{m}$ sections were processed for immunhistochemistry (Imht) using PAP technique.

Immunohistochemistry. Incubated sections in a methanolhydrogen peroxidase mixture for 10 mins (to quench the endogenous peroxidase activity), then with blocking solution containing $1 \%$ normal goat serum and $0.2 \%$ Triton X 100 in PBS (0.1M) for $1 \mathrm{hr}$ at room temperature (RT). Drained out the blocking solution. Incubated with primary antibody i.e. mouse monoclonal anti-ER- $\alpha$ antibody (1:100, France, Marseille) for $72 \mathrm{hrs}$ at $4^{\circ} \mathrm{C}$, then with secondary antibody goat-anti-mouse IgG, for ER for $8 \mathrm{hrs}$ at $4^{\circ} \mathrm{C}$ followed by with monoclonal mouse PAP $(1: 100)$ for $4 \mathrm{hrs}$ at $4^{\circ} \mathrm{C}$. After every incubation sections were washed with PBS. Incubated with substrate chromogen (3, 3' diaminobzidine tetrahydrochloride $(\mathrm{DAB})$ reaction mixture at $\mathrm{RT}$ in dark for 10 mins. Washed with tap water first and then distilled water. Mounted the stained sections on gelatin coated (subbed slides) and let dry overnight. Dehydrated the mounted sections by passing through graded alcohols. Cleared in xylene. Mounted with DPX and observed under the microscope.

\section{RESULTS}

The ER immunoreactive (IR) structures were identified as neuronal perikarya, dendritic processes and axonal terminals. Positive neurons were seen distributed in all the regions of hippocampus and exhibited morphological characters of non pyramidal cells (interneurons). ER-IR neurons were seen in all the subfields of Cornua ammonis (CA) with some regional variations. The immunoreactive distribution pattern varied not only region wise but layer wise also.

CA3-CA2. Maximum immunoreactivity (IRty) was seen in stratum oriens with a few ER +ve neurons in stratum pyramidale. Neurons of different shapes and sizes showing variable immunoreactivity were seen (Fig 1a,b). Bipolar neurons and fusiform neurons showed ER-IRty in the cytoplasm as well as nuclei (cytonuclear) whereas larger neurons which were multipolar exhibited cytoplasmic staining. On the basis of ER IRty one could easily differentiate CA3a from CA3c zone (Fig 1a,b). The IR 


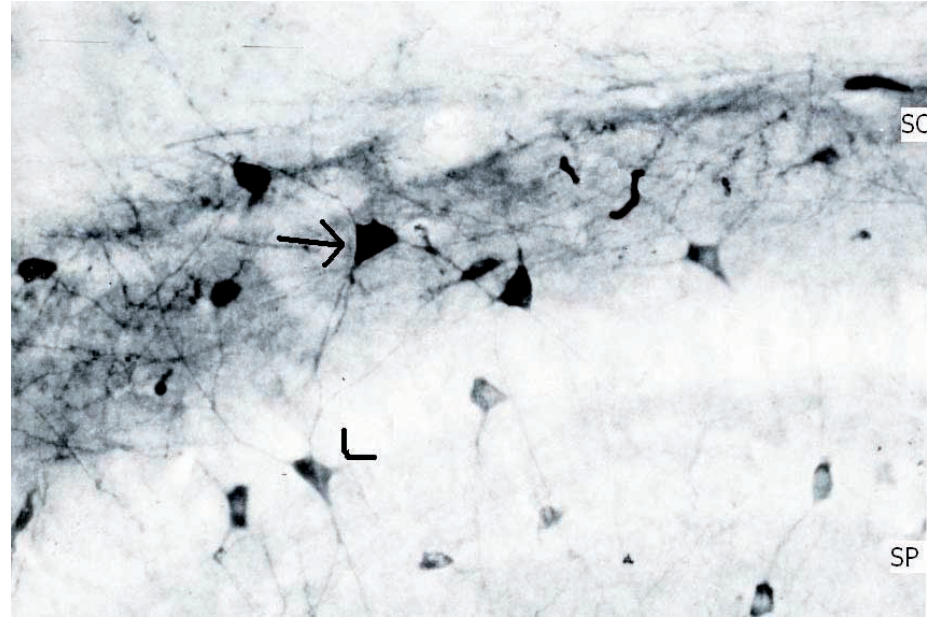

Fig. 1(a).Photomicrograph of coronal section of rat hippocampus showing abundant ER +ve neurons in CA3a region Arrow indicating neuron in the Stratum Oriens (SO) and arrowhead showing a neuron in the Stratum Pyramidale (SP). PAP staining. Scale bar $-50 \mu \mathrm{m}$.

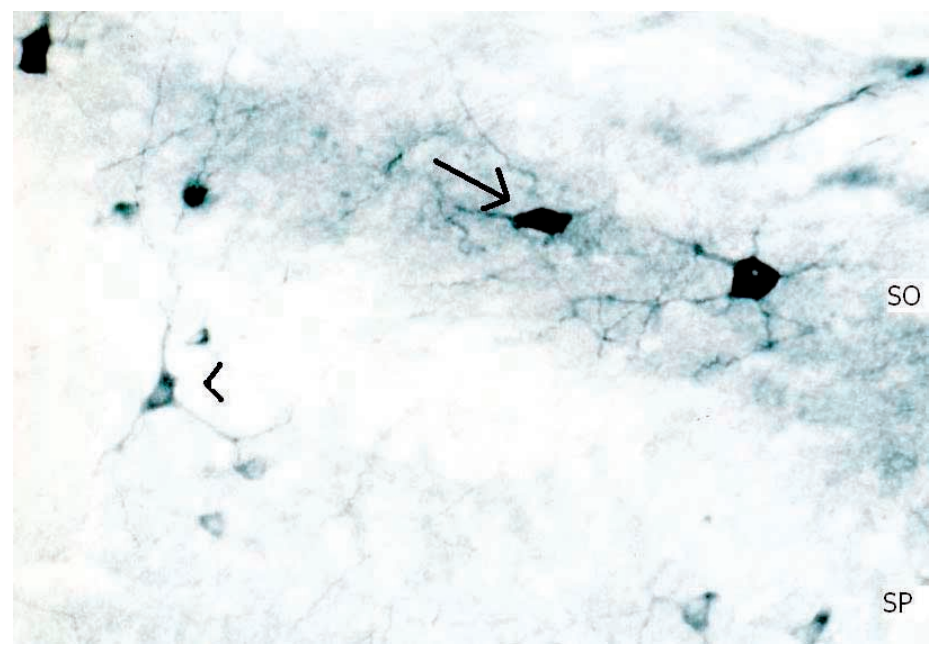

Fig. 1(b).Photomicrograph of coronal section of rat hippocampus showing a few ER +ve neurons in CA3c region Arrow indicating neuron in the Stratum Oriens (SO) and arrowhead showing a neuron in the Stratum Pyramidale (SP). Note: Neurons of this region are slightly larger than CA3a region. PAP staining. Scale bar $-50 \mu \mathrm{m}$

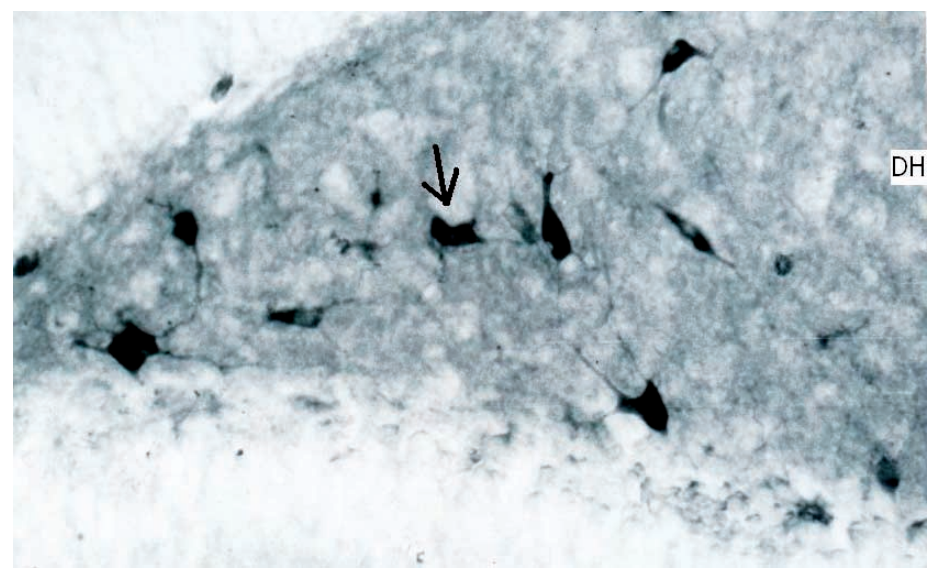

neurons were more in number but smaller in size in former (Fig.1a). The size of IR neurons as well as the staining intensity appeared to be steadily decreasing from hilus to CA2 region.

CA1. ER-IRty was much less both in terms of positive perikarya as well as terminal staining in CA1 as compared to CA3-CA2. Nevertheless the distributions pattern in varions layers appeared to be the same as in CA3-CA2. There were small to medium sized neurons lightly stained and the staining was seen mainly in the cytoplasm. The number of ER positive perikarya appeared to decrease steadily as one moved towards the subiculum.

Dentate Gyrus (DG). The IR neurons were seen mainly in the hilus (Fig. 2).The staining was seen both in cytoplasm as well as nuclei (cytonuclear) and was very intense on the whole. This area also showed intense terminal staining. No IR neurons were observed in the crest area. IR neurons were mainly seen in polymorphic layer of ectal limb \& endal limb. The neurons were small to medium sized and of various shapes. No IR neurons were seen in granule cell layer \& molecular layer of both the limbs.

\section{DISCUSSION}

The present study provides detailed information on distribution of ER- $\alpha$ immunoreactivity in rat hippocampus for the first time until the date where it has not only dealt with region wise distribution but has also correlated the immunoreactive pattern with neuronal morphology. As mentioned earlier that hippocampus is associated with higher cognitive processes of learning and memory, thus the understanding of neurochemical nature of its neurons is of much importance.

We observed variations in ER IR pattern in different subfields of CA as well as in DG. Thus maximum IRty (both in terms of number of IR neurons as well as neuropil staining) was observed in CA3-CA2 as compared to CA1. In DG maximum

Fig. 2.Photomicrograph of coronal section of rat hippocampus showing ER +ve neurons in Dentate hilus(DH). Note: staining intensity as well as number of positive neurons are more compared to other regions of Dentate Gyrus (DG). PAP staining. Scale bar $-50 \mu \mathrm{m}$ 
IRty was observed in hilar region and in ectal limb. Morphologically the immunoreactive neurons of $\mathrm{CA}$ region as well of dentate gyrus appeared to be interneurons.

As mentioned previously there are no detailed reports available on the distribution of ER+ve neurons in hippocampus to compare our results with. Nevertheless, a limited description by Weiland et al. has reported maximum incidence of ER IR cells in the dentate hilus. The above investigators along with Milner et al. (2001) have further observed a high incidence of ER+ve neurons in stratum radiatum of CA1. In our layerwise analysis, we have observed maximum IRty in stratum oriens of CA3. The discrepancy in results may be explained on the basis that Weiland et al. had localized only the $\mathrm{b}$ isoform of ER, whereas Milner et al. (2001) had used rabbit polyclonal antibody against ER-a using $\mathrm{ABC}$ method of immunohistochemistry. The antibody used in our study was mouse monoclonal specific to a isoform of the receptor. The same may be the reason for difference in the intracellular staining pattern seen between the two studies. Weiland et al. observed staining mostly in neuronal nuclei with only a few neurons showing cytoplasmic staining, whereas Milner et al. observed cytoplasmic staining. In present investigations the staining reaction was localized mainly to cytoplasm. Nuclei were stained in a few neurons as well. In our study for the first time on the basis of immunoreactivity it was possible to differentiate between different zones of CA3 i.e. CA3a, CA3c. The former zone exhibited much higher IRty than latter. The staining pattern of neurons varied with their size i.e. smaller neurons exhibited cytonuclear type of staining whereas large sized neurons showed cytoplasmic staining. Hence our study is an important step toward understanding the detailed and region-wise ER IRty of hippocampal region.

\section{ACKNOWLEDGEMENTS}

This work which is a part of post graduate thesis submitted in 2001 was supported by the grants from All India Institute of Medical Sciences, New Delhi, India. The authors would like to thank Dr. R. D. Mehra for her excellent guidance and assistance during the study.

RAI, A. L. \& JESWAR, U. Inmunolocalización del receptor de estrógeno alfa en el hipocampo de rata hembra adulta. Int. J. Morphol., 28(2):483-487, 2010.

RESUMEN: El estudio fue diseñado para demostrar el patrón de distribución inmunorreactivo (IR) detallado de los receptores estrogénicos (RE) en el hipocampo de 15 ratas Wistar, hembras, adultas, en fase de estro. Fueron obtenidas secciones $30 \mu \mathrm{m}$ de grosor con un crióstato, de la región del hipocampo fijadas por perfusión (4\% de paraformaldehído tamponado). Las secciones fueron procesadas, por libre flotación, para la inmunolocalización de RE utilizando anticuerpo monoclonal de ratón anti-ER- $\alpha$ con la técnica de PAP. Los resultados mostraron la presencia de neuronas inmunorreactivas ER en todos los subcampos del hipocampo con algunas variaciones. En el cuerno ventral (CA) la mayor zona RE positiva (+ ve) de las neuronas se localizaron en la región CA3. El análisis de las capas mostró la localización máxima en la región del estrato oriens (SO). En otros subcampos y capas de la CA las neuronas IR fueron comparativamente menores en número. Las características morfológicas de todas las neuronas RE + ve resultaron ser interneuronas tanto en el CA como en el giro dentado (DG). ventral.

PALABRAS CLAVE: Receptor de estrógeno a; Receptor de estrógeno b; Cerebro; Hipocampo; Interneuronas; Cuerno

\section{REFERENCES}

Adams, M. M.; Fink, S. E.; Shah, R. A.; Janssen, W. G.; Hayashi, S.; Milner, T. A.; McEwen, B. S. \& Morrison, J. H. Estrogen and aging affect the subcellular distribution of estrogen receptor-alpha in the hippocampus of female rats. J. Neurosci., 22(9):3608-14, 2002.

Blaustein, J. D. \& Olster, D. H. Gonadal steroid hormone receptors and social behaviors. In: Balthazart, J. (Ed). Advances in Comparative and Environmental Physiology. Vol. 3. Berlin, Springer-Verlag, 1989. pp.23-35.
Fillit, H.; Weinreb, H.; Cholst, I.; Luine, V.; McEwen, B.; Amador, R. \& Zabriskie, J. Observations in a preliminary open trial of estradiol therapy for senile dementiaAlzheimer's type. Psychoneuroendocrinology, 11:33745, 1986.

Gould, E.; Woolley, C. S.; Frankfurt, M. \& McEwen, B. S. Gonadal steroids regulate dendritic spine density in hippocampal pyramidal cells in adulthood. J. Neurosci., 10:1286-91, 1990. 
Koch, M. \& Ehret, G. Immunocytochemical localization and quantitation of estrogen-binding cells in the male and female (virgin, pregnant, lactating) mouse brain. Brain Res., 489:101-12, 1989.

Kuiper, G. G. J. M.; Enmark, E.; Pelto-Huikko, M.; Nilsson, S. \& Gustafsson, J. A. Cloning of a novel estrogen receptor expressed in rat prostate and ovary. Proc. Nat. Acad. Sci. USA, 93:5925-30, 1996.

Kuiper, G. G. J. M.; Carlsson, B.; Grandien, K. A. J.; Enmark, E.; Haggblad, J.; Nilsson, S. \& Gustafsson, J. A. Comparison of the ligand binding specificity and transcript tissue distribution of estrogen receptor a \& b. Endocrinology, 138:863-70, 1997.

Laflamme, N.; Nappi, R. E.; Drolet, G.; Labrie, C. \& Rivest, $\mathrm{S}$. Expression and neuropeptidergic characterization of estrogen receptors (ER a and ER b) throughout the rat brain: anatomical evidence of distinct roles of each subtype. J. Neurobiol., 36:357-78, 1998.

Milner, T. A.; McEwen, B. S.; Hayashi, S.; Li, C. J.; Reagan, L. P. \& Alves, S. E. Ultrastructural evidence that hippocampal alpha estrogen receptors are located at extranuclear sites. J. Comp. Neurol., 429:355-71, 2001.

Milner, T. A.; Ayoola, K.; Drake, C. T.; Herrick, S. P.; Tabori, N. E.; McEwen, B. S.; Warrier, S.; \& Alves, S. E. Ultrastructural localization of estrogen receptor beta immunoreactivity in the rat hippocampal formation. $J$. Comp. Neurol., 491:81-95, 2005.

Mitra, S. W.; Hoskin, E.; Yudkovitz, J.; Pear, L.; Wilkinson, H. A.; Hayashi, S.; Pfaff, D. W.; Ogawa, S.; Rohrer, S. P.; Schaeffer, J. M.; McEwen, B. S.\& Alves, S. E. Immunolocalization of estrogen receptor $\mathrm{b}$ in the mouse brain: comparison with estrogen receptor a. Endocrinology, 144:2055-67, 2003.

McEwen, B. S. \& Alves, S. E. Estrogen actions in the central nervous system. Endocr. Rev., 48(7):8-15, 1999.

O'Neil, M. F.; Means, L.W.; Poole, M. C. \& Hamm, R. J. Estrogen affects performance of ovariectomized rats in two-choice water-escape working memory task. Psychoneuroendocrinology, 21:51-65, 1996.

Shughrue, P. J.; Bushnell, C. D. \& Dorsa, D. M. Estrogen receptor Messenger Ribonucleic acid in female rat brain during the estrous cycle: A comparision with ovariectomized female and intact males. Endocrinology,
131:381-8, 1992.

Shughrue, P. J.; Lane, M. V. \& Merchanthaler, I. Comparative distribution of estrogen receptors a \& b mRNA in the rat central nervous system. J. Comp. Neurol., 388:50725, 1997.

Toran-Allerand, C. D. Estrogen and the brain: beyond ERalpha, ER-beta, and 17beta-estradiol. Ann. N. Y. Acad. Sci., 1052:136-44, 2005.

Woolley, C. S.; Gould, E.; Frankfurt, M. \& McEwen, B. S. Naturally occurring fluctuation in dendritic spine density on adult hippocampal pyramidal neurons. J. Neurosci., 10:4035-9, 1990.

Woolley, C. \& McEwen, B. S. Estradiol regulates hippocampal dendritic spine density via an N-methylD-aspartate receptor dependent mechanism. J. Neurosci., 14:7680-7, 1994.

Weiland, N. G.; Orikasa, C.; Hayashi, S. \& McEwen, B. S. Distribution and hormone regulation of estrogen receptor immunoreactive cells in the hippocampus of male and female rats. J. Comp. Neurol., 388:603-12, 1997.

\author{
Correspondence to: \\ Dr. Anju Lata Rai \\ House no. -458, Block C, Sector 19 \\ Noida, Uttar Pradesh \\ INDIA \\ Email: anjulata72@gmail.com \\ usha0606@yahoo.com
}

Received: 23-11-2009

Accepted: 24-03-2010 
